\title{
Extent of Teachers' Classroom Management Practices for Quality Teaching and Learning in Secondary Schools in Ebonyi State
}

\author{
Dr. Isaac N. Nwankwo \\ E. M. P. Department \\ NAU \& Co-ordinator \\ Research and Publication Unit \\ Ebonyi State College of Education \\ Ikwo, Ebonyi State \\ Nigeria \\ Mr. Omebe Matthew \\ Ebonyi State College of Education \\ Ikwo, Ebonyi State \\ Nigeria \\ Mrs. Anikeze Christiana \\ Ebonyi State College of Education \\ Ikwo, Ebonyi State \\ Nigeria
}

\begin{abstract}
This study ascertained extent of teachers' classroom management practices for quality teaching and learning in public and private secondary schools in Ebonyi State of Nigeria. The research design adopted is descriptive survey. The population for this study comprised 3275 secondary school teachers while the sample for this study comprised 1641 respondents. A researcher-developed instrument duly validated by experts was used for data collection. The overall scale reliability coefficient for the instrument was 0.82 . The researchers collected data with the help of six research assistants. Mean and t-test were used in data analysis. Findings indicated that teachers in private schools used instructional monitoring for quality teaching and learning in the classroom to a low extent. Accordingly, it was among others recommended monitoring team should be set up in all the schools in Ebonyi State.
\end{abstract}

Keywords: Teachers; Classroom; Management practice; Quality; Teaching and Learning; Public School; Private School.

\section{Introduction}

The classroom determines what the child eventually becomes morally and academically. This goes to prove how indispensable the provision of adequate, conducive, suitable and child-friendly classroom is for school children to achieve their goals (Omenyi, 2007). This implies that the classroom occupies a very important place in any system of education. It therefore implies that the classrooms need to be properly managed. Many research studies (Adegbesan 2011; Asiyai 2011; Iwuji 2012; and Osakwe 2014 reported that a conducive classroom environment is needed to promote students' academic achievement in secondary schools. Given the above situation, there is the need for proper management of the available classrooms in secondary schools for quality and sustainability in the system.

Managing classrooms means more than avoiding chaos in the classroom but establishing a routine that enables learning activity to proceed smoothly. Arikewuyo (2001) saw classroom management as the process of efficiently and effectively organizing the classroom so that learning objectives can be achieved. Organizing classroom efficiently and effectively for positive learning outcome is largely dependent on the ability of the teachers. According to Biodun (2000) good classroom management helps to prevent unnecessary discipline problems by students in the classroom and promotes good behaviour and better academic results. 
From a pedagogical standpoint, teaching and learning can only occur in an orderly classroom. Orderliness here does not only imply quiet or rigid classroom but it refers to classroom whose activities indicate engaging students in meaningful learning. The teacher does this by adopting some practices.

Classroom management practices according to, Asiyai (2011) also refers to the tactics the teacher employs in the classroom for better teaching and learning. These tactics of organizing the students in the class include: having better seating arrangements, co-coordinating their activities, monitoring their behaviours, ensuring effective learning process, providing instruction through interactive communication, getting feedback from students, preparing and utilizing instructional materials in facilitating learning, maintaining discipline among learners, evaluating learning outcome, serving as a role model, reinforcing their performance through motivational techniques, giving clear and simple directions, among others. Osakwe (2014) refers to classroom management practices as the tactics or methods adopted by teachers to ensure decorum in the classroom and thus create a healthy and conducive atmosphere for learning. Therefore, classroom managers must be abreast with these effective techniques and practices for effective teaching to take place and quality to be assured in education in Nigeria. The classroom must be arranged properly to accommodate the students, seats and tables, instructional materials and so on. It is also the responsibility of the classroom teacher most especially in secondary schools to make sure that the students are monitored while instruction is on, maintain good teacher/student relationship, communicate effectively for better understanding, and most importantly, make good use of reinforcement to motivate the students for better performance (Ahmad 2011; Canary 2011; Dunbar 2004; Ibode 2004). In Nigeria, classroom management practices are intended for teachers to provide the necessary supports to ensure that students are really learning. But if the teachers lack these abilities, control and order that enhance teaching and learning process will be inhibited.

Classroom management practices are a crucial part of teachers' success in creating a safe and effective learning environment for students' quality education. Therefore teachers should know how to use and apply strategies that will allow and help students learn (Zuckerman, 2007). Arguing further Zuckerman went on to enumerate some of these practices as:

- Good classroom arrangement. To manage the few facilities provided for students' usage.

- Use of incentives to motivate students and provide counselling services for those with deviant behaviours.

- Make rules and regulations simple and understandable and be consistent in enforcing their plan the lessons using the scheme of work as a guide, and present lessons from known to unknown facts.

- Delegate specific responsibilities daily to students and request for regular update and reports from such students.

- Treat the students' cases justly and equally without bias/partiality-set up a positive behaviour for rewards and punishment system.

- Modelling - the teacher should serve as a role model for the students to emulate.

Jones and Jones (2012), there are many classroom management practices which the classroom teacher should choose from to meet the individual needs of their students for effective learning, discipline and control that enhance quality secondary education. They include:

- Developing a solid understanding of the students' personal, psychological and learning aspirations.

- Establishing positive student- teacher relationships that aid students psychological needs.

- Using instructional methods that facilitate optimal learning by responding to students learning needs.

- Using organizational and group management methods that maximize students on task behaviours and

- Using counselling and behavioural methods that involves students in examining and correcting their inappropriate behaviours.

Wisethrinthong, Sirisuthi and Weangsamoot (2002) opined that these classroom management practices remain the key factors in the attainment of set goals of the learning process and ensuring quality educational system. For him, the following areas of classroom are among the most essential areas that need to be put in place to ensure a smooth learning environment.

a. Physical classroom atmosphere

b. Chalkboard arrangement

c. Classroom arrangement

d. Time management in the classroom 
e. Handing instructional materials

f. Communication for effective control

g. Sustaining of learners in the class.

Wisethrinthong, Sirisuthi and Weangsamoot went further to say that physical classroom atmosphere/arrangement of every classroom is most important point of concern in classroom management. This is because the physical setting of classroom has been viewed as an important and determining factor for motivating learners to learn or determining them from learning. Azubuike (2012) and Ali (2007) in support of the above assertion, were of the view that, if the classroom getting is orderly beautiful and comfortable in terms of lighting organization, temperature conditions, learners will be happy, eager and willing to learn. However, a poorly arranged classroom which is sited near a noisy area or street, factory or market place and which does not have the right classroom facilities can lead to lack of interest, boredom, fatigue indiscipline and negative learning attitudes on the part of the learners.

Ahmad (2011) also stated the important classroom management practices as follows:

1) Organization

a) Seating arrangement

b) Organizing material

c) Organization and care of instructional equipment

d) Classroom rules, routines and procedures etc.

2) Communication -good communication has great important for good classroom management

3) Monitoring

4) Lesson strategies and lesson delivery

5) Questioning

Weinsten and Evartson (2006) enumerated five (5) practices a classroom teacher must engage in order to achieve educational goals. They are:

1) Develop caring supportive relationships with and among the students

2) Organize and implement instruction in ways to optimize students' access to learning.

3) Promote the development of students' social skills and self-regulation

4) Use appropriate interventions to against students with behaviour problems

5) Serve as a role model.

From the contributions of different authors on what classroom management practices are, this study focused two classroom management practices namely use of reinforcement to motivate students and teachers' classroom arrangement. Ahmad (2011) had observed that classroom management practices are predicted on the extent the teacher is enhances students' learning. It is therefore imperative to carry out this study to analyze the extent of use of classroom management practices by teachers in public and private secondary schools for quality teaching and learning in Ebonyi state of Nigeria.

\section{Statement of the Problem}

In the area of study, some schools have more than 40 students per class as against the teacher student ratio of 1:40 recommended by the National Policy on Education (FGN, 2013). This situation has led to spreading resources thinly and inability of the teachers to manage the class effectively, thereby, affecting the quality of education. As a result of this, indiscipline among students abounds and quality hindered. The need for the classroom teachers to possess the necessary skills to manage instruction and behaviour in secondary schools in Ebonyi state seems to be neglected. Many studies have not been carried out on the extent of teachers' use of classroom management practices for quality teaching and learning in public and private secondary schools in the state. Hence the need for this study to upgrade the little information that is almost not in existence.

\section{Research Questions}

The following four research questions will guide the study.

1. What is the extent of teachers' reinforcement of students for quality teaching and learning in public and private secondary schools in Ebonyi State?

2. What is the extent of teachers' classroom arrangement for quality teaching and learning in public and private secondary schools in the state? 


\section{Hypotheses}

Four hypotheses will be tested at 0.05 level of significance. They are as follows;

1. There is no significant difference in the mean ratings of public and private secondary school teachers on the extent of their reinforcement of students for quality teaching and learning in public and private secondary schools in Ebonyi State.

2. There is no significant difference in the mean ratings of public and private secondary school teachers on the extent of their classroom arrangement for quality teaching and learning in public and private secondary schools in Ebonyi state.

\section{Research Method}

The study was conducted in Ebonyi State of Nigeria. The research design adopted is descriptive survey. The population for this study comprised all the three thousand, two hundred and seventy five (3275) secondary school principals and teachers in the area of study. The sample for this study comprised 1641 (one thousand, six hundred and forty-one) respondents selected through proportionate $d$ random sampling technique. Researchers-developed instrument titled "Classroom Management Practices for Quality Teaching (CMPQT) was used for data collection. To ensure face and content validity of CMPQT, three copies of it was presented to three experts: two lecturers in Educational Administration in Ebonyi State University Abakaliki for validation, and one lecturer in Measurement and Evaluation from the same university. The reliability of the instrument was determined using Cronbach Alpha on data collected from a sample of 30 principals and 30 teachers respectively from secondary schools in Enugu State. The overall scale reliability coefficient for the instrument was 0.82 . The researcher collected data with the help of six research assistants who are teachers in secondary schools in Ebonyi State. In answering the research questions, mean was used. The scores of the private and public secondary school respondents were presented in separate columns for each research question. In analyzing the data, mean ratings of 3.50-4.00 was regarded as very great extent, 2.50 - 3.49 great extent, 1.50-2.49 low extent and 1.00-1.49 was regarded as very low extent. The null hypotheses were tested at the 0.05 level of significance using t-test.

\section{Presentation of Results}

Research Question 2: What is the extent of teachers' reinforcement of students for quality teaching and learning in public and private secondary schools in Ebonyi State?

Table 2: Mean responses of public and private secondary schools teachers on the use of reinforcement for quality teaching and learning.

\begin{tabular}{|c|c|c|c|c|c|}
\hline & & $\begin{array}{l}\text { Public } \\
(\mathrm{N}=82\end{array}$ & $\begin{array}{l}\text { School } \\
5)\end{array}$ & $\begin{array}{l}\text { Private } \\
(\mathrm{N}=816)\end{array}$ & School \\
\hline $\mathrm{S} / \mathrm{N}$ & To what extent do you & Mean & Remark & Mean & Remak \\
\hline 14 & Make use of praise to motivate your students & 2.62 & GE & 3.17 & GE \\
\hline 15 & $\begin{array}{l}\text { Reinforcement students' positive behavior or performance in the } \\
\text { class. }\end{array}$ & 2.44 & LE & 3.14 & GE \\
\hline 16 & $\begin{array}{l}\text { Make use of punishment whenever there is misbehaviour in your } \\
\text { class. }\end{array}$ & 2.51 & GE & 3.15 & LE \\
\hline 17 & $\begin{array}{l}\text { Recommend well behave or best performed students in your class } \\
\text { for recognition or award in the school. }\end{array}$ & 2.41 & LE & 3.20 & GE \\
\hline 18 & Reinforce positive behavior with the use of tokens and gifts & 2.35 & LE & 3.22 & GE \\
\hline 19 & $\begin{array}{l}\text { Use humour to stimulate students' interest or reduce classroom } \\
\text { tension. }\end{array}$ & 2.42 & LE & 2.44 & LE \\
\hline 20 & Flog the students when they misbehavior in the classroom & 2.62 & GE & 2.86 & GE \\
\hline 21 & Give feedback to the students on their performance and behavior & 2.34 & LE & 3.18 & GE \\
\hline 22 & $\begin{array}{l}\text { Pay extra attention to a student who is not performing well in } \\
\text { your class. }\end{array}$ & 2.41 & LE & 3.57 & VGE \\
\hline & Grand Mean & 2.47 & LE & 3.13 & GE \\
\hline
\end{tabular}

The result in table 2 shows that the grand mean for public schools on the extent of the teachers' use of reinforcement to motivate the students is 2.47 indicating low extent while the grand mean for private schools is 3.13 indicating great extent. This indicates that while teachers in public schools use reinforcement for quality teaching and learning to a low extent, teachers in private schools use it to a great extent. 
Research Question 4: What is the extent of teachers' classroom arrangement for quality teaching and learning in public and private secondary schools in Ebonyi state?

Table 4: Mean responses of public and private schools on extent of classroom arrangement for teaching and learning

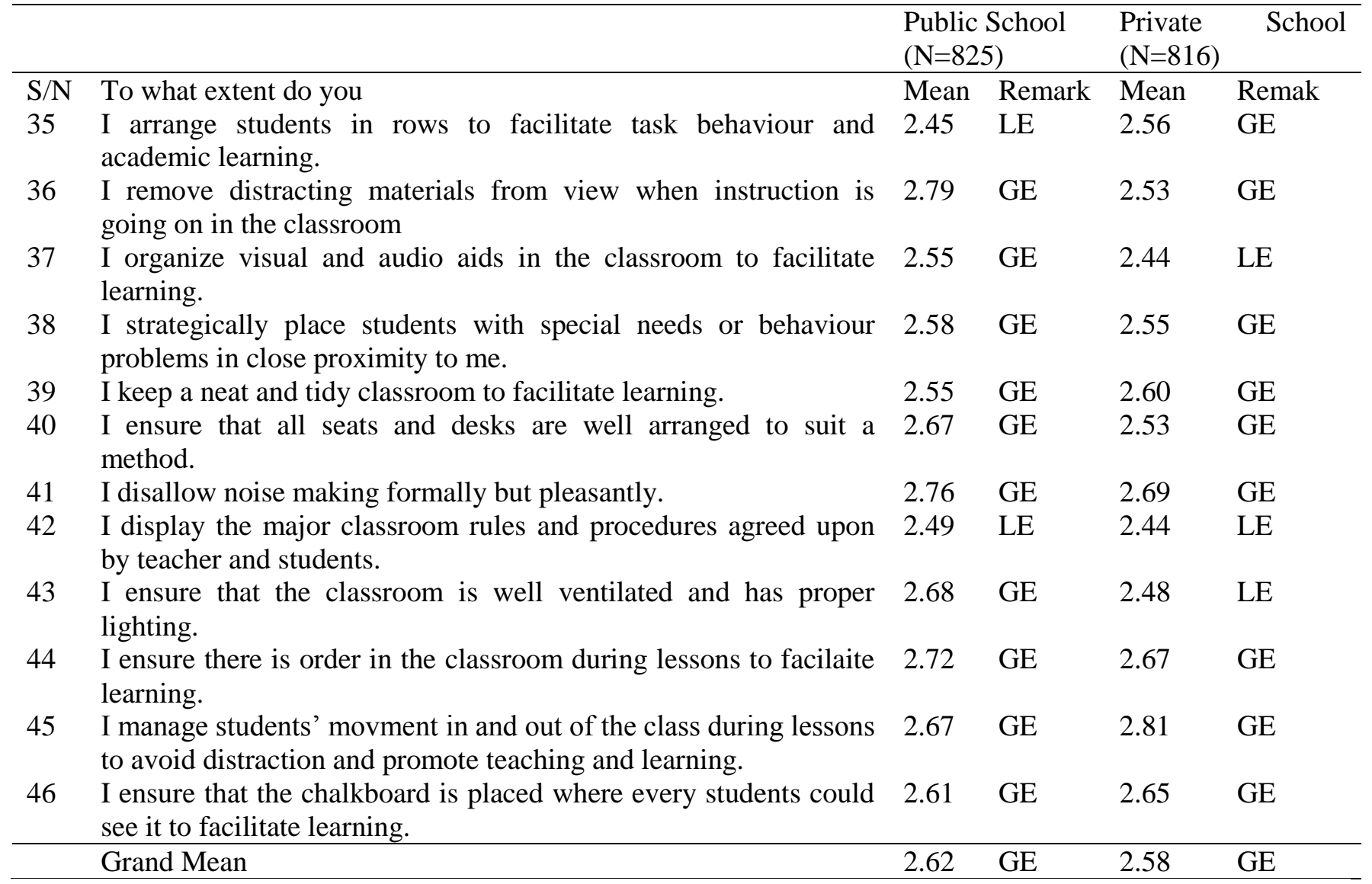

From results in Table 4, the grand mean for public schools on how they arrange their classrooms for quality enhance teaching and learning is 2.62 while the a and mean for private schools is 2.58 . This shows that the teachers in public and private secondary schools use classroom arrangement for quality teaching and learning to a great extent.

Hypothesis 2: There is no significant difference in the mean ratings of public and private secondary school teachers on the extent of their reinforcement of students for quality teaching and learning in public and private secondary schools in Ebonyi State.

Table 6: z-test comparison of public and private school teachers' mean responses on the extent of their use of reinforcement to motivate the students to learn

\begin{tabular}{|c|c|c|c|c|c|c|c|c|}
\hline & $\begin{array}{l}\text { Public } \\
\text { School } \\
\text { (N=825) }\end{array}$ & & $\begin{array}{l}\text { Private } \\
\text { School } \\
(\mathrm{N}=816)\end{array}$ & & & & & \\
\hline & Mean & SD & Mean & SD & df & z-cal & z-crit & Decision \\
\hline $\begin{array}{l}\text { Extent of } \\
\text { Reinforcement }\end{array}$ & 2.47 & 1.14 & 3.13 & 0.93 & 1256 & 2.03 & 1.96 & Signifcant \\
\hline
\end{tabular}

The result in table 6 reveals that the z-cal value of 2.03 was greater than the critical value z-value of 1.96 at alpha level of 0.05 and degree of freedom (df) 1639. This means that the difference in the mean responses of public and private school teachers' responses on the extent of their use of reinforcement to motivate the students to learn is significant. Therefore, the null hypothesis was rejected. 
Hypothesis 4: There is no significant difference in the mean ratings of public and private secondary school teachers on the extent of their classroom arrangement for teaching and learning in public and private secondary schools in Ebonyi state.

Table 8: z-test comparison of public and private school teachers' mean responses in their classroom arrangement to enhance teaching and learning

\begin{tabular}{|c|c|c|c|c|c|c|c|c|}
\hline & $\begin{array}{l}\text { Public } \\
\text { School } \\
(\mathrm{N}=825)\end{array}$ & & $\begin{array}{l}\text { Private } \\
\text { School } \\
(\mathrm{N}=\mathbf{8 1 6})\end{array}$ & & & & & \\
\hline $\begin{array}{l}\text { Extent of Classroom } \\
\text { arrangement }\end{array}$ & $\begin{array}{l}\text { Mean } \\
2.64\end{array}$ & $\begin{array}{l}\text { SD } \\
2.44\end{array}$ & $\begin{array}{l}\text { Mean } \\
2.58\end{array}$ & $\begin{array}{l}\text { SD } \\
2.57\end{array}$ & $\begin{array}{l}\text { Df } \\
1639\end{array}$ & $\begin{array}{l}\text { z-cal } \\
1.86\end{array}$ & $\begin{array}{l}\text { z-crit } \\
1.96\end{array}$ & $\begin{array}{l}\text { Decision } \\
\text { Not } \\
\text { Signifcant }\end{array}$ \\
\hline
\end{tabular}

The z-test analysis in table 8 shows that the z-cal value of 1.86 was less critical value $z$-value of 1.96 at alpha level of 0.05 and degree of freedom (df) 1639. This is an indication that the difference in the mean responses of public and private school teachers' responses in their classroom arrangement to enhance teaching and learning was not significant. Therefore, the null hypothesis was not rejected.

\section{Summary of Findings}

The findings of the study could be summarized as follows:

1. Teachers in private secondary schools to a great extent use high reinforcement skills for quality teaching and learning than the teachers in public secondary schools.

3. Teachers in both public and private schools use classroom arrangement for quality teaching and learning to a low extent.

6. Hypothesis two shows that there is significant different between teachers in public and those in private schools on their use of reinforcement for quality teaching and learning.

8. Hypothesis four shows that there is no significant different between teachers in public and those in private schools in their classroom arrangement for quality teaching and learning.

\section{Discussion of Findings}

Research question two and null hypothesis two as analyzed on table 2 focused on the extent of the teachers' use of reinforcement to motivate students for quality teaching. The results show that teachers in private schools to a great extent use adequate reinforcement methods that can effectively motivate the students'for quality teaching and learning than teachers in public secondary schools in Ebonyi state. The implication of the finding therefore, is that teachers in private secondary schools in Ebonyi state greatly reinforce their students so as to create conducive environment for quality teaching and learning to take place. The finding is supported by that of Ahmed (2011) that reported that the application of reinforcement as a classroom management strategy is higher among private secondary teachers than their counterparts in public schools but indicated that effective behaviour change is needed among the public school teachers to bring about proper use of reinforcement to motivate the students to learn. This is in agreement with Asiyai (2011) who stated that the use of reinforcement and reward is an effective classroom technique that promotes teaching and learning in the classroom

The same table two also indicates that teachers in public schools to a very high extent flog the students when they misbehave in the classroom than their counterparts in private secondary schools. The results also show that teachers in public schools to a very low extent pay extra attention to students who are not performing well in their class. Therefore it was observed that teachers in private secondary schools to a great extent use positive reinforcement to motivate their students to learn than the teachers in public schools. Browne (2013) agreed with the findings of this study when he emphasized that the use of positive reinforcement strategies is an effective means of classroom management that strengthens positive behaviour in the classroom.

Research questions five and null hypothesis five addressed how the teachers arrange their classrooms to enhance teaching and learning in the classroom. The results of the data analyses are presented in table 5. The results indicate that teachers in public and private secondary schools in Ebonyi state agreed that good arrangement of classrooms to enhance teaching and learning can come through arranging students to facilitate task behaviour, removing distracting materials, organizing audio-visual aids, strategically placing students with special needs, keeping neat and tidy classroom, etc. 
This implies that effective classroom arrangement by teachers in both public and private secondary schools in Ebonyi state will enhance classroom management for teaching and learning. This means that teachers in public and private secondary school in the state agree that classroom arrangement is an important factor in the process of teachers' classroom management and control. This agrees with Idu (2012) who found out that teachers should possess the necessary skill in class arrangement for efficient teaching and learning. The seats, desks should be well arranged in rows. The result of this study is not in agreement with Ahmad (2011) who found out in his study that classroom arrangement is better practiced in private secondary school than in public secondary. Furthermore, the findings of this study agrees with Kukuru 2011 who realized that physical arrangement of the classroom is one of the basic classroom principles every teacher must possess to enhance quality teaching and learning.

\section{Conclusion}

Classroom management is an important issue in teaching and learning. Proper classroom management depends on the teacher. The teacher manages the class well when the environment is conducive for the students. Therefore, this study has shown that teachers in private and public secondary schools in inbra state make use of instructional monitoring and reinforcement skills to manage their classrooms for quality assurance but, private secondary schools utilized them in great extent than the public secondary schools. This also shows that, public and private school teachers have low usage of teacher-student relationship and low extent of use of effective communication skills as classroom management practices for quality teaching and learning in Ebonyi state.

\section{Recommendations}

Based on the findings of the study, the following recommendations were made:

1. Monitoring team should be set up in all the schools in Ebonyi State. This will enable the government, proprietors and stakeholders to know why private schools to some extent perform better in classroom management than the public schools.

2. Training and retraining of teaching staff should be the watchword of school management. Workshops should be organised by the federal and state government annually to refreshen the teaching methodology of teachers. This will create enabling environment for teachers to improve where they are lacking in classroom management in schools.

3. Adequate staff welfare should be mandatory in schools. Adequate remuneration should be provided to the teachers in the classroom at all levels. This will make them to be dedicated to their classroom duties and management.

4. Classroom management content in teacher education training colleges and institutions should be given much more priority with the sole aim of improving the standard of teaching in our classes.

\section{References}

Adegbesan S.O. (2010).Establishing quality assurance in Nigerian education system: Implications for educational managers. Educational Research and Reviews. 5(7) 380-384 http://www.academic journal.Org /ERR.

Adeyemo, S.A. (2012).The relationship between effective classroom management \& students academic achievement. European Journal of Educational studies. 4(3), 206-213.

Ahmad, M. (2011). Application of classroom management strategies in public and private sector at school level in Pakistan. Journal of manager science, Vol IV No. 1 poages 55-66.

Ali, M.O (2007). Classroom management In H.M Bellow \& A.B Abubakar (Eds.) Issues in educational management. A study material for Nigeria teachers. Kaduna.

Anho R.O. (2015) Principals and teachers' assessment of teachers' classroom management effectiveness in Delta State. Basic Research Journal of Education and Review.

Arikewuyo. M.O (2004). Effective funding and quality assurance in the Nigeria education system. A paper presented at the $1^{\text {st }}$ National Conference of the Institute of Education, Olabisi Onabanjo University, AgoIwoye.

Asiyai, R.I. (2011), Effective Classroom Management techniques for secondary schools. International MultiDisciplinary Journal, Ethiopia. 5 (1), 18-25.

Azubuike, P. I (2012) Classroom Management as a control strategy for promoting Quality education in Nigeria Mediterranean Journal of Social Sciences 3(16): 20-27. 
Canary, H. (2011) Communication and organizational knowledge: Temporary issues for theory and practice: Florence, KY: Taylor \& Francis.

Durbar, C. (2004). Best practices in classroom management. Michigan State University. University Outreach and Engagement.

Edwards, C. (2000). Classroom management and discipline, New York: Macmillan College.

FGN (2013) National Policy on Education. (6 ${ }^{\text {th }}$ edition) Lagos: NERDC Press.

Ibode, O.F. (2004). Classroom and use of Instructional aids. West African Journal of Education 24/(l) 22-29.

Iwuji, L (2012). The problems of classroom management in secondary schools in Nigeria: Study of secondary schools in Owerri Municipal Council of Imo State. Unpublished Dissertation, Department of Education Foundation. University of Port Harcourt

Jones, V.F and Jones, T. S (2012). Comprehensive classroom management: Creating communities of support solving problems $\left(10^{\text {th }}\right.$ edition). Prentice HallKaduna: 978-88.

Ogunu, M. (2000) Introduction to education management. Benin City: Mgbagun Publishers.

Omenyi, A. S. (2007). Leadership and school management: A problem-based approach. J. Goshen Publishers, Awka

Sowell, 1.C. H.(2013). Classroom management strategies: The impact on students' achievement. Unpublished dissertation, Liberty University, Lynchburg.

Wistethrinthong, K. Sirisuthi, C. \& Weangsmoot, V. (2012). The development of classroom management system for the educational extension schools. European Journal of Social Sciences 30(2): 313-320. www.liste.org

Zuckerman, J. (2007). Classroom management in secondary schools. A study of student teachers ' successful strategies. High Beam Researcher Inc. USA. 